\title{
Hvilket ansvar har dommeren for å legge til rette for et godt avgjørelsesgrunnlag i en sivil sak?
}

Maria Astrup Hjort, førsteamanuensis, Ph. D.

Maria Astrup Hjort (født 1980) er cand.jur. fra Universitetet i Oslo (2006) og disputerte med avhandlingen «Tilgang til bevis i sivile saker - særlig om digitale bevis» i 2015. Hun er ansatt som førsteamanuensis ved Institutt for offentlig rett, Universitetet i Oslo.

I artikkelen klargjøres begrepet «avgjørelsesgrunnlag» og det trekkes et skille mellom faktisk og rettslig avgjørelsesgrunnlag. Deretter presenteres ulike innfallsvinkler til vurderingen av hva som er et godt avgjørelsesgrunnlag, og hvordan aktiv saksstyring, materiell prosessledelse og bevisavskjæring kan legge til rette for å oppnå et godt faktisk avgjørelsesgrunnlag. Det vurderes så i hvilken grad dommeren kan og bør gripe inn for å påvirke avgjørelsesgrunnlaget i en positiv retning.

\section{Innledning}

I april 1992 stod den såkalte Factoring Finans-saken for Høyesterett. ${ }^{1}$ Factoring Finans A/S hadde inngått en factoringavtale med Sam-Teknikk A/S som blant annet innebar at Sam-Teknikk forpliktet seg til å overdra alle sine kundefordringer til factoringselskapet. Sam-Teknikk gikk senere konkurs og Factoring Finans krevde innbetalt utestående fra en av Sam-Teknikks kunder. Kunden erklærte imidlertid motregning med krav som var oppstått som følge av mislighold av avtalen med SamTeknikk. Spørsmålet for Høyesterett var om dette motregningskravet kunne gjøres gjeldende.

Helt mot slutten av ankemotpartens prosedyre, men før replikk og duplikk, lener en av høyesterettsdommerne seg over bordet og spør partene: «..., men er dette kravet overdratt?» Selve innholdet i factoringavtalen hadde ikke vært behandlet i forhandlingene så langt, og replikkvekslingen fikk dermed et ganske annet forløp enn det partene opprinnelig hadde lagt opp til.

Høyesterettsdommerens spørsmål på tampen av forhandlingene var nok stilt for å få et godt avgjørelsesgrunnlag i saken, men spørsmålet kom i tolvte time, og da var partenes muligheter for å områ seg begrenset. Spørsmålet fikk også følger for avgjørelsen. Det som ble sakens sentrale spørsmål hadde knapt blitt behandlet under hovedforhandlingen, og spørsmålet om motregning, som partene hadde prosedert på, kom som et obiter dictum. Det blir omtalt i avgjørelsen at retten hadde vurdert om saken burde ha vært utsatt eller om lagmannsrettens dom burde vært opphevet og saken hjemvist til lagmannsretten for ny bevisførsel og prosedyre i anledning spørsmålet. Saken var imidlertid ført som en prinsippsak av stor betydning, og av hensyn til ankemotparten mente Høyesterett at «saken nå burde få sin endelige avgjørelse». ${ }^{2}$

Et «avgjørelsesgrunnlag» kan defineres som det retten kan bygge sin avgjørelse på. Avgjørelsesgrunnlaget i en sak kan deles i to deler, det rettslige og det faktiske. Det rettslige avgjørelsesgrunnlaget er de rettsreglene som kan anvendes på det aktuelle forholdet, og det faktiske avgjørelsesgrunnlaget er bevisene som er ført i saken, og som underbygger partenes påstander. Begge deler må være tilstrekkelig klargjort for at retten skal kunne foreta en subsumsjon og gjøre seg opp en mening om det individuelle rettsspørsmålet. Så fremt saken er behandlet muntlig i domstolen, skal

\footnotetext{
${ }^{1}$ Rt. 1992 s. 504.

${ }^{2}$ Rt. 1992 s. 504 på s. 509.
} 
avgjørelsen etter tvisteloven $\S 11-1$ første ledd treffes på grunnlag av behandlingen i rettsmøtet. ${ }^{3}$ Det er et overordnet mål for saksbehandlingen å oppnå en materielt riktig avgjørelse, og et godt avgjørelsesgrunnlag er en forutsetning for å kunne oppnå en materielt riktig avgjørelse. Men hva er egentlig et godt avgjørelsesgrunnlag? Og hvilken mulighet har dommeren for å sikre dette? Og ikke minst; hvilket ansvar har han eller hun for å sørge for at avgjørelsesgrunnlaget blir godt? Dette er spørsmål som blir behandlet i denne artikkelen.

\section{Rettslig avgjørelsesgrunnlag}

\subsection{Introduksjon}

Den ene delen av avgjørelsesgrunnlaget, det rettslige avgjørelsesgrunnlaget, er regulert i tvisteloven $\S 11-3$. Her gis retten ansvar for å «sørge for et betryggende avgjørelsesgrunnlag for rettsanvendelsen». Det er med andre ord rettens ansvar å finne frem til det rettslige grunnlaget for det konkrete tilfellet. Partene vil som regel presentere rettslig argumentasjon både under saksforberedelsen og under prosedyren, men retten er ikke bundet av anførsler om rettsreglene. Tvert imot, retten har en selvstendig plikt til å sørge for at rettsanvendelsen blir riktig. Regelen har likevel sine begrensninger. Dette er begrunnet i disposisjonsprinsippet. Disposisjonsprinsippet innebærer at partene selv velger hvordan de vil ordne sine rettsforhold, og herunder hvordan de vil løse eventuelle tvister. ${ }^{4}$ Prinsippet er med andre ord en stadfesting av partenes autonomi. Partene velger selv om de vil benytte domstolsapparatet for å $1 \varnothing$ se tvisten, ${ }^{5}$ og det innebærer at når partene kommer til domstolen med en tvist, bestemmer partene også selv hvilke(t) krav som skal behandles. ${ }^{6}$ Domstolen kan bare avgjøre de krav som er reist i saken, og avgjørelsen må ligge innenfor rammen av de påstander partene har nedlagt, og retten kan bare bygge på de påstandsgrunnlag som er påberopt, jf. tvisteloven § 11-2 første ledd. Retten kan heller ikke til fordel for en part anvende en fravikelig rettsregel som parten ikke $\emptyset$ nsker å påberope seg. ${ }^{7}$

For å kunne anvende de aktuelle rettsreglene riktig, må retten ha et forsvarlig rettslig avgjørelsesgrunnlag for rettsanvendelsen. ${ }^{8}$ I mange saker vil ikke dette by på problemer. Retten kan vanligvis orientere seg og finne frem til rette bestemmelser, og partene har egeninteresse i a fremheve aktuelle bestemmelser. I noen tilfeller kan det imidlertid tenkes at rettsgrunnlaget er vanskeligere tilgjengelig. Dersom det aktuelle kravet for eksempel baseres på stedlig sedvanerett eller fremmed rett, kan retten etter tvisteloven $\S 11-3$ bestemme at det skal føres bevis om rettsspørsmål eller tillate partene å føre slike bevis. Retten bestemmer da omfanget av bevisføringen og hvordan den skal gjennomføres. Slik bevisførsel skjer imidlertid bare unntaksvis og bare dersom «rettsanvendelsen ikke fullt forsvarlig kan belyses på annen måte». Det understrekes i forarbeidene at proporsjonalitetsprinsippet må stå sentralt i vurderingen av om slik bevisførsel skal skje. ${ }^{9}$ Det overordnede målet om en konsentrert og effektiv saksbehandling legger også begresninger for hvor stor grad av bevisførsel som kan tillates om rettsspørsmål. ${ }^{10}$

\footnotetext{
${ }^{3}$ Andre avgjørelser treffes etter tvisteloven $§ 11-1$ annet ledd «på grunnlag av sakens dokumenter og behandlingen i rettsmøter».

${ }^{4}$ Jo Hov, Rettergang i sivile saker, Oslo 2017 s. 53. Heretter: Hov (2017).

${ }^{5}$ Jens Edvin A. Skoghøy, Tvistelфsning, 3. utgave, Troms $\varnothing$ 2017, s. 570. Heretter: Skoghøy (2017).

${ }^{6}$ Robberstad, Sivilprosess, 4. utgave, Bergen 2018, s. 16. Heretter: Robberstad (2018).

7 Tore Schei mfl., Tvisteloven. Kommentarutgave, 2. utgave, Oslo og Skien 2013, s. 394. Heretter: Schei mfl. (2013).

${ }^{8}$ NOU 2001: 32 B s. 705.

${ }^{9}$ Ot.prp. nr. 51 (2004-2005) s. 405.

${ }^{10}$ Se NOU 2001: 32 A s. 133 om disse hensynene.
} 


\subsection{Et godt rettslig avgjørelsesgrunnlag}

Et spørsmål i forlengelsen av kravet i § 11-3 om en forsvarlig rettsanvendelse, er hva som er et godt rettslig avgjørelsesgrunnlag. Intuitivt vil man kunne svare at et forsvarlig avgjørelsesgrunnlag også må være et godt avgjørelsesgrunnlag. Denne forsvarlighetsvurderingen ligger hos retten, og dersom retten mener at det rettslige avgjørelsesgrunnlaget ikke er forsvarlig, kan, som sagt, mulighetene i § 11-3 anvendes.

Et godt rettslig avgjørelsesgrunnlag må kunne defineres som alle relevante rettsregler som det aktuelle faktum naturlig kan subsumeres under. I mange saker vil retten ikke ha problemer med å selv finne frem til et dekkende rettslig avgjørelsesgrunnlag. Dersom det er tvist om salg av et hus, og saksøker påstår at huset har mangler som kjøper måtte kjenne til, vil retten raskt kunne finne frem til avhendingslova § 3-7, jf. § 3-1. Og dersom tvisten gjelder et tre på naboeiendommen som saksøker vil ha hugget ned, må retten finne frem til grannelova $§ 3$. Det vil ikke nødvendigvis gjøre det rettslige avgjørelsesgrunnlaget bedre om flere andre bestemmelser trekkes inn.

I en stadig mer global verden vil det imidlertid ikke alltid være så lett å få oversikt over all relevant regulering. Gjennom EØS-avtalen bindes Norge stadig opp til nye reguleringer, og ved grenseoverskridende saker, vil bilaterale avtaler og folkerettslige forpliktelser kunne få betydning. Det kan til tider være utfordrende for retten å ha oversikten over det samlede rettslige bildet i alle saker. Et godt rettslig avgjørelsesgrunnlag vil måtte favne alle relevante kilder fra både nasjonal og internasjonal rett, så lenge dette kan ha betydning for avgjørelsen. Selv om det til tider kan være vanskelig å finne frem til relevante rettskilder, vil det sjelden være tvil om hva som er relevant. Når alle relevante rettskilder er gjort til en del av det rettslige avgjørelsesgrunnlaget, taler det for at det rettslige avgjørelsesgrunnlaget også er godt.

Et element som det imidlertid også kan argumenteres for at bør spille inn i vurderingen av om det rettslige avgjørelsesgrunnlaget er godt, er partenes kunnskap om avgjørelsesgrunnlaget. Retten har anledning til å bygge på en annen rettsanvendelse enn partene har påberopt, uten først å måtte gi dem anledning til å uttale seg om spørsmålet. ${ }^{11}$ Tvistemålsutvalget foreslo at kravet til kontradiksjon skulle gjelde også for det rettslige avgjørelsesgrunnlaget, men forslaget ble fjernet av departementet. Begrunnelsen var at man ville unngå at retten måtte ta opp igjen forhandlingene dersom den etter at saken var tatt opp til doms ble oppmerksom på rettslige standpunkter som ikke var påberopt av partene. ${ }^{12}$ Når det er sagt, understreket departementet at retten fortsatt ville ha plikt til å bidra til å få avklart partenes standpunkter til rettslige spørsmål. Gjennom reglene om aktiv saksstyring - som jeg kommer tilbake til - vil denne avklaringen ideelt skje tidlig i saksforberedelsen. Dermed reduseres faren for at retten først etter at saken er tatt opp til avgjørelse, ser grunn til å anvende andre rettsregler eller legge til grunn at de har et annet innhold enn det som er påberopt av partene. ${ }^{13}$

Selv om det med andre ord ikke er noen plikt til å orientere partene om rettslige synspunkter, bør retten tilstrebe kontradiksjon om dette spørsmålet. Et rettslig avgjørelsesgrunnlag som både retten og partene er innforstått med, vil i større grad være et godt rettslig avgjørelsesgrunnlag.

\section{$3 \quad$ Faktisk avgjørelsesgrunnlag}

\subsection{Introduksjon}

Ansvaret for det faktiske avgjørelsesgrunnlaget stiller seg ganske annerledes enn det rettslige. Mens det er retten som har ansvaret for det rettslige avgjørelsesgrunnlaget i en sivil sak, er det partene som har ansvaret for det faktiske. Dette er begrunnet i forhandlingsprinsippet. I forlengelsen av disposisjonsprinsippet inneholder tvisteloven en regel om at det er partene som har ansvaret for å

\footnotetext{
${ }^{11}$ Schei mfl. (2013) s. 396.

12 Ot.prp. nr. 51 (2004-2005) s. 168.

13 Ot.prp. nr. 51 (2004-2005) s. 168.
} 
skaffe til veie det faktiske grunnlaget for rettens avgjørelse, jf. tvisteloven $§ 11-2$ annet ledd. ${ }^{14}$ Dette kalles forhandlingsprinsippet. Forhandlingsprinsippet dreier seg om arbeidsdeling, mens disposisjonsprinsippet dreier seg om hvem som bestemmer, retten eller partene. ${ }^{15}$

Forhandlingsprinsippet er begrunnet $i$ at det er partene som er nærmest de faktiske forhold, og som dermed forutsettes å vite både hvilke bevis som best opplyser saken og hvor disse befinner seg. Effektivitetshensyn taler også for at dette er en god arbeidsfordeling.

Denne hovedregelen gjelder imidlertid bare for saker underlagt fri rådighet. I saker der partenes rådighet er begrenset, vil retten etter tvisteloven § 11-4 ikke være bundet av partenes prosesshandlinger «lenger enn dette er forenlig med de offentlige hensyn». «Offentlige hensyn» forstås her vidt. Det sentrale spørsmålet er om rettsforholdet er slik at hensyn til andre interesser enn dem sakens parter kan råde over, nødvendiggjør begrensninger i partenes adgang til å råde over saken. ${ }^{16}$ I disse tilfellene vil dommeren etter tvisteloven $§ 21-3$ annet ledd ha en plikt til å sørge for at bevisførselen gir et forsvarlig faktisk avgjørelsesgrunnlag. Typiske eksempler på saker der partenes rådighet er begrenset, er saker om bruk av tvang i helse- og sosialsektoren og foreldretvister etter barnelova.

Om vi vender tilbake til hovedregelen om at det er partene som har ansvar for det faktiske avgjørelsesgrunnlaget, vil vi se at heller ikke i saker med fri rådighet gjelder denne hovedregelen absolutt. Regelen må avstemmes mot et annet sentralt prinsipp i sivilprosessen, nemlig prinsippet om materielt riktige avgjørelser. Målsetningen om at rettsbehandlingen skal resultere i en materielt riktig avgjørelse er så grunnleggende at mange prosessrettsfremstillinger knapt setter av plass til å drøfte den. ${ }^{17}$ Uten et mål om å komme frem til en materielt riktig avgjørelse, vil behandling av saker i domstolen kunne minne om et lotteri, der partene håper å trekke vinnerloddet. Så lenge en dommer har materielle regler å forholde seg til, må det være en overordnet målsetning for rettsanvendelsen at resultatet blir materielt riktig. En slik tanke figurerer også implisitt i tittelen på denne artikkelen. Det ville være uinteressant å diskutere ansvaret for et godt avgjørelsesgrunnlag, hvis ikke avgjørelsesgrunnlaget skulle danne utgangspunkt for en slutning mot et materielt riktig resultat.

Basert på et $\emptyset$ nske om en materielt riktig avgjørelse, vil retten i saker med fri rådighet etter § 11-2 annet ledd annet punktum kunne sørge for bevisføring dersom partene ikke motsetter seg dette. Dette er imidlertid et unntakstilfelle, og retten vil vanligvis ikke ha plikt til å ta initiativet til bevisføring ut over det partene selv presenterer. ${ }^{18}$ En utvidet plikt for partene til å gi tilgang til bevis, slik tvisteloven legger opp til, innebærer en begrensning av disposisjonsprinsippet. Det er fremdeles partenes ansvar å sørge for bevisføringen, men gjennom reglene om bevistilgang legges det føringer for hvilke bevis det skal gis tilgang til, noe som igjen kan ha betydning for hvilke bevis som føres for retten.

\subsection{Et godt faktisk avgjørelsesgrunnlag}

\subsubsection{Innledning}

I utgangspunktet er det altså partenes ansvar å underbygge sine påstander med bevis, slik at det faktiske avgjørelsesgrunnlaget blir godt. Men et godt faktisk avgjørelsesgrunnlag er ikke en statisk størrelse, og det finnes flere innfallsvinkler til vurderingen av hvordan dette målet kan nås. Før man

\footnotetext{
${ }^{14}$ Det er en viss uenighet i teorien om hvordan grensen mellom de to prinsippene skal trekkes. Uenigheten knytter seg hovedsakelig til om begrensningen av de påberopte påstandsgrunnlagene, jf. § 11-2 (1), følger av disposisjonsprinsippet eller forhandlingsprinsippet. Robberstad (2018) s. 14 og Hov (2017) s. 53 og Skoghøy (2017) s. 570 legger til grunn at dette følger av disposisjonsprinsippet, mens Schei mfl. (2013) s. 383 anfører at dette hører inn under forhandlingsprinsippet.

${ }^{15}$ Robberstad (2018) s. 15.

${ }^{16}$ NOU 2001: 32 B s. 707.

${ }^{17}$ Se for eksempel Hov (2017) s. 46 og Skoghøy (2017) s. 537.

${ }^{18}$ Schei mfl. (2013) s. 392.
} 
vurderer i hvilken grad domstolen kan påvirke det faktiske avgjørelsesgrunnlaget, må man ta stilling til hva man anses som et godt faktisk avgjørelsesgrunnlag.

\subsubsection{Domstolens funksjoner}

Vurderingen av hva som er et godt faktisk avgjørelsesgrunnlag avhenger av hvilken funksjon domstolene utøver. Domstolens funksjon er nemlig mangfoldig.

På det individuelle plan er det et mål for domstolen at parter i tvist kan få avklart sine konflikter og håndhevet sine rettigheter. Samtidig kan det være viktig å finne en løsning som begge parter kan leve med. I tvisteloven § 8-1 er det et uttalt mål at retten «på ethvert trinn av saken [skal] vurdere muligheten for å få rettstvisten helt eller delvis løst i minnelighet gjennom mekling eller rettsmekling». I saker der partene skal forholde seg til hverandre også etter avgjørelsen, kan det være viktigere å finne en minnelig løsning enn å få en materielt riktig avgjørelse. Dette kan prege dommerens vurdering av hvordan det skal legges til rette for et godt avgjørelsesgrunnlag.

På det samfunnsmessige plan fyller domstolen en rekke andre funksjoner. ${ }^{19}$ Domstolen skal sikre den materielle rettens gjennomslag, og gjennom det styre vår adferd. Tanken er at individet innretter seg etter regelverket når det er en visshet om at reglene blir håndhevet. Uten denne domstolsfunksjonen ville samfunnet raskt ha mistet respekten for gjeldende regler. Domstolen fungerer med andre ord som et slags ris bak speilet.

Videre skal domstolen sikre rettsavklaring og rettsutvikling. Det at domstolens avgjørelser blir eksempler til etterfølgelse, innebærer at avgjørelsene får virkning ut over den enkelte sak. Denne prejudikatsvirkningen tvinger dommeren til å se saken i en større sammenheng, og det kan også påvirke vurderingen av hva som er et godt avgjørelsesgrunnlag. Uten god forberedelse og gode og relevante prosedyrer, er det ikke forsvarlig å avsi generelle og prinsipielle avgjørelser. ${ }^{20}$

Avslutningsvis har domstolen også en funksjon i å foreta kontroll av andre myndigheters utøvelse av myndighet. Denne funksjonen viser seg på flere nivåer. For det første har domstolen en kontrollfunksjon overfor de andre statsmaktene. Domstolen kontrollerer at utøvende myndighet handler i samsvar med gjeldende regelverk og at lovgivende myndighet gir lover innenfor Grunnlovens rammer og folkerettens forpliktelser. For det andre har domstolen en kontrollfunksjon for forvaltningsvedtak, og for det tredje har domstolen har en kontrollfunksjon ved behandling av rettigheter etter EMK eller EØS-avtalen. ${ }^{21}$ Idet en stats organer vurderes under ett ved anklage om brudd på konvensjonene, vil domstolens kontrollfunksjon også innebære en form for intern kontroll. ${ }^{22}$

Selv om mange av funksjonene vil virke samtidig, vil hva vi anser som et godt avgjørelsesgrunnlag farges av hvilke(n) funksjon(er) som er mest dominerende i den enkelte sak. Derfor er det viktig for dommeren å være seg bevisst hvilken bakgrunn avgjørelsesgrunnlaget vurderes opp mot. Hva som er godt for partene i saken, kan være noe annet enn det som er godt for samfunnet, eller det som er godt for den rettslige utviklingen på feltet. Momenter som kan være av betydning for å vurdere hvilken av domstolens funksjoner som står sentralt, og som igjen kan påvirke vurderingen av hva som er et godt avgjørelsesgrunnlag, kan være saksområde, partskonstellasjon, om partene er selvprosederende eller blir representert av advokat, hva kravet gjelder og hvor prinsipiell saken er.

Hva som er et godt avgjørelsesgrunnlag vil også være avhengig av hvor i domstolsystemet saken skal behandles. I saker for tingretten vil avgjørelsen først og fremst være rettet inn mot å løse den konkrete saken, og det preger vurderingen av hva som er et godt avgjørelsesgrunnlag på dette stadiet. Annerledes stiller det seg i saker for Høyesterett. Her er det gjerne ett enkelt prinsipielt rettsspørsmål

\footnotetext{
${ }^{19}$ Skoghøy (2017) s. 3-5.

${ }^{20}$ Erik Eldjarn, Materiell prosessledelse, Oslo 2016, s. 71. Heretter: Eldjarn (2016).

${ }^{21}$ Eldjarn (2016) s. 73.

${ }^{22}$ Eldjarn (2016) s. 73.
} 
som skal avklares, og detaljene i den konkrete saken kan være av mindre betydning. Et eksempel på dette er når det føres pilotsaker for Høyesterett. Det viktige er å få et prejudikat som kan anvendes i tilsvarende saker. Det er altså domstolens funksjon som rettsavklarer og rettsutvikler som er sentral. Hvordan løsningen blir i den konkrete saken, kan være av mindre betydning i dette perspektivet. Spørsmålet om hva som er et godt avgjørelsesgrunnlag, stiller seg med andre ord annerledes enn for tingrettsavgjørelsene.

\subsubsection{Robusthet}

Så langt har jeg drøftet hva som er et godt faktisk avgjørelsesgrunnlag med et noe mer overordnet perspektiv. En mer konkret og teknisk måte å vurdere spørsmålet om hva som er et godt avgjørelsesgrunnlag, er å vurdere to faktorer; nemlig mengden bevis og disse bevisenes bevisverdi. Intuitivt vil man kanskje tro at avgjørelsesgrunnlaget blir bedre og bedre jo flere bevis man får og jo høyere bevisverdien er. At bevisverdien er høy, er selvfølgelig bra, men det er ikke nødvendigvis slik at avgjørelsesgrunnlaget blir bedre jo flere bevis partene klarer å presentere. Å høre det femtende vitnet forklare seg om det samme som de fjorten foregående, gjør ikke nødvendigvis avgjørelsesgrunnlaget noe bedre. Selv om prinsippet om fri bevisføring underbygger partenes anledning til å føre de bevis de selv vil, må retten ha anledning til å begrense mengden. Dersom retten skal forholde seg til unødvendig store mengder bevis, kan man tvert imot risikere at de sentrale bevisene drukner i eventualiteter.

Magne Strandberg introduserte i sin doktoravhandling begrepet «robusthet» om en bevissituasjon og definerte robusthet som «fravær av skjørhet overfor ny relevant informasjon». ${ }^{23}$ Han mener sannsynlighet ikke er tilstrekkelig som parameter for å vurdere en bevissituasjon, og argumenterer for at man også må ha bevissituasjonens robusthet som parallelt parameter. For å vise forskjellen mellom sannsynlighet og robusthet, gir han følgende eksempel:

«Vi har ført beviset $h_{1}$, og vi sier at sannsynligheten er 0,85 for påstanden a gitt dette beviset. Deretter føres $h_{2}$ som er ugunstig for a, slik at sannsynligheten for $h_{1}$ og $h_{2}$ er 0,45 . Etter dette føres et tredje bevis $h_{3}$ som er gunstig for a, og som gjør at sannsynlighetsgraden for a igjen er 0,85 . Selv om sannsynligheten er den samme $(0,85)$ før og etter at de to nye bevisene ble ført, er saken blitt bedre opplyst, $\left[\ldots\right.$ og] graden av robusthet er blitt høyere.» ${ }^{24}$

Ethvert manglende bevis som kan gjøre en forskjell i sannsynlighetsgrad, er ifølge Strandberg en robusthetsmangel, og en bevissituasjon er robust først når ny relevant informasjon ikke utgjør noen forskjell utover selve tilkomsten av nye bevis..$^{25}$ «Mens sannsynlighet dreier seg om hvor godt bevist en påstand er gitt en viss bevissituasjon, er robusthet en måte å gradere bevissituasjonens kvalitet.» ${ }^{26}$

Én måte å vurdere hva som er et godt avgjørelsesgrunnlag, er å vurdere om avgjørelsesgrunnlaget er robust. Nye bevis som fører til at saken blir bedre opplyst, bør tillates ført for retten. Samtidig må bevis som ikke påvirker graden av robusthet begrenses. Det er slett ikke upraktisk at dommeren må håndtere begge disse ytterlighetene i en og samme sak.

Graden av robusthet kan også ses i sammenheng med drøftelsen ovenfor om domstolenes funksjoner. Dersom domstolens sentrale funksjon i en sak er å kontrollere andre myndigheters utøvelse av myndighet, vil graden av robusthet $\mathrm{i}$ avgjørelsesgrunnlagets antagelig vurderes annerledes enn for eksempel i en sak der meklingsfunksjonen står sentralt.

\footnotetext{
${ }^{23}$ Magne Strandberg, Beviskrav i sivile saker, Bergen 2012, s. 542. Heretter: Strandberg (2012).

${ }^{24}$ Strandberg (2012) s. 55-56.

${ }^{25}$ Strandberg (2012) s. 542-543.

${ }^{26}$ Strandberg (2012) s. 55.
} 
Å få et robust avgjørelsesgrunnlag, er i mange tilfeller et ideal mer enn et realistisk mål. I mindre saker slår hensynet til proporsjonalitet hardere inn, og ønsket om et godt avgjørelsesgrunnlag presses av hensynet til konsentrasjon og hurtighet. Spørsmålet blir dermed ofte ikke hva som er et robust avgjørelsesgrunnlag, men hva som er robust nok. I Domstolsadministrasjonens årsrapport for 2016 blir «[d]omstolenes samfunnsoppdrag»i all hovedsak relatert til spørsmål om effektivitet og saksavvikling. ${ }^{27}$ I kampen mot klokka og voksende restanser, kan det til tider synes som om domstolen godtar at avgjørelsesgrunnlaget hverken er godt eller robust, men er mer opptatt av en måloppnåelse i form av mange saker gjennom systemet.

\subsubsection{Den enkelte dommers oppfatning}

Det som gjør vurderingen av hva som er et godt faktisk avgjørelsesgrunnlag så utfordrende, er at vurderingen må gjøres konkret av den enkelte dommer i den enkelte sak. Og den enkelte dommer kan ha ulikt syn på hva et godt faktisk avgjørelsesgrunnlag er. Peter Westberg, professor i prosessrett ved Lunds universitet, beskriver i en artikkel om materiell prosessledelse forskjellige dommertyper, og hvordan disse handler ulikt i spørsmålet om materiell prosessledelse. ${ }^{28}$ Han beskriver det han kaller den rettstekniske dommeren, rettsstatsdommeren, velferdsrettsdommeren og den realpolitiske dommeren. Alle handler innenfor lovens rammer, men gjennom en konkret sak viser han hvordan dommertypene resonnerer forskjellig og gir forskjellig veiledning. Det er ingen grunn til å tro at dette eksempelet ikke har overføringsverdi til norske forhold. Som akademiker må man gjerne mene noe om hva som er et godt avgjørelsesgrunnlag, men i og med at denne typen spørsmål sjelden blir løftet opp på et høyere nivå, vil det i praksis være vanskelig å forme den enkelte dommers oppfatning om hva som til enhver tid vil være et godt avgjørelsesgrunnlag.

\subsection{Hvordan kan dommeren legge til rette for et godt faktisk avgjørelsesgrunnlag?}

\subsubsection{Innledning}

Vanligvis vil partene ha insitamenter til å få det faktiske avgjørelsesgrunnlaget blir best mulig. I noen tilfeller lykkes likevel ikke partene med dette arbeidet. Det kan det være mange grunner til. Parten kan være selvprosederende og ikke ha skjønt hvilke bevis det er nødvendig å underbygge påstanden med, saken kan ha tatt en overraskende vending slik som i Factoring Finans-saken nevnt innledningsvis, og dette kan ha gitt behov for ny bevisførsel, eller parten kan, selv om vedkommende er representert ved prosessfullmektig, ha oversett et påstandsgrunnlag. I disse situasjonene er spørsmålet om dommeren skal være med og påvirke for å legge til rette for et godt avgjørelsesgrunnlag. Avhengig av hva som svekker avgjørelsesgrunnlaget, kan dommeren påvirke avgjørelsesgrunnlaget gjennom aktiv saksstyring, materiell prosessledelse, eller gjennom bevisavskjæring. Hensynet til en materielt riktig avgjørelse står her mot hensynet til partsautonomi. I hvilken grad skal dommeren gripe inn i partenes mer eller mindre bevisste prosesshandlinger for å sikre et godt avgjørelsesgrunnlag? Vektingen av hensynene må her gjøres konkret.

\subsubsection{Aktiv saksstyring}

En forsiktig måte å påvirke avgjørelsesgrunnlaget, er gjennom aktiv saksstyring. En av de markante endringene fra tvistemålsloven og til tvisteloven var nettopp vektlegging av dommerens mer aktive posisjon. Etter tvisteloven § 11-6 første ledd har retten plikt til å drive aktiv saksstyring, ved å følge opp saken slik at den «effektivt og forsvarlig kan bringes til avslutning». Ideen i forarbeidene er at

\footnotetext{
${ }^{27}$ Domstolsadministrasjonens årsrapport for 2016 s. 20.

${ }^{28}$ Peter Westberg, «Kasuistiska marginalanteckningar eller sedvanerättslig arkipelag - några reflexioner över underrätternas normbildning i frågor om materiell prosessledning i tvistemål», Juridisk Tidskrift vid Stockholms universitet, 1995/1996 s. 74-92 på s. 76.
} 
dommeren skal være på banen helt fra saken kommer inn til retten ved stevning. ${ }^{29}$ Straks tilsvar er inngitt, skal retten kalle partene inn til rettsmøte for å legge en plan for den videre behandlingen av saken. Dette er regulert i tvisteloven § 9-4. En av mange punkter på agendaen er en gjennomgåelse bevisføringen, og en avklaring av om partene trenger tilgang til noen bestemte bevis, om det skal gjøres bevisopptak eller om det bør oppnevnes sakkyndig. Dommeren får dermed kunnskap om og oversikt over det som tenkes ført og har her en mulighet til å sørge for at sentrale bevis blir ført, og at bevis som ikke tilfører saken noe nytt, avskjæres.

Prinsippet om aktiv saksstyring gjelder gjennom hele saksgangen. Tvisteloven § 9-13 gir retten anledning til å foreta justeringer også under hovedforhandling, for å sikre at gjennomføringen skjer konsentrert og forsvarlig. Retten gis også anledning til å nekte unødige gjentakelser, unødig omfattende behandling og behandling av forhold som er uten betydning for saken.

En del av det å drive aktiv saksstyring vil også være det å stille forberedt til rettsmøtene. Tiden der dommeren kom til rettsmøte og ikke visste annet om saken enn navnet på partene og hva kravet gjaldt, er forbi. Ved å på et tidlig tidspunkt få strukturert saken og lagt en plan for gjennomføringen, reduseres muligheten for overraskelser og forsinkelser. Dermed bidrar også dommeren til å legge til rette for et godt avgjørelsesgrunnlag.

\subsubsection{Materiell prosessledelse}

Det er en nær sammenheng mellom aktiv saksstyring og materiell prosessledelse. I forarbeidene står det om aktiv saksstyring at «stevningen må gjennomgås med henblikk på å få rettet opp feil og mangler som ellers kunne være til hinder for at saken kunne fremmes. Det samme gjelder for feil som på annen måte kan forsinke fremdriften av saken eller ellers være uhensiktsmessig for en effektiv fremdrift». ${ }^{30}$ Samtidig står det i tvisteloven $§ 11-5$ tredje ledd om rettens veiledningsplikt at retten skal virke for at tvistespørsmål blir klarlagt, og at partenes påstander og standpunkter til faktiske og rettslige spørsmål blir klargjort. Å skille mellom disse aktivitetene er vanskelig i praksis. Erik Eldjarn skriver i sin doktoravhandling om materiell prosessledelse at «rettens aktive saksstyring fungerer som en katalysator for rettens veiledning». ${ }^{31}$ Ved at dommeren på et tidlig tidspunkt setter seg inn i saken, kommer dommeren i posisjon til å veilede tidlig i prosessen. Dermed utvides også muligheten for $\varnothing \mathrm{kt}$ veiledning.

Selv om det kan være vanskelig å skille mellom aktiv saksstyring og materiell prosessledelse, er selve innretningen forskjellig. Formålet med aktiv saksstyring er å planmessig kunne gjennomføre rettssakene innenfor en fornuftig tidsramme, for dermed å oppnå en mest mulig strømlinjeformet prosess. Dette er altså ingen egenverdi i det å drive aktiv saksstyring, men det er med på å operasjonalisere andre prinsipper og verdier, for eksempel forsvarlighet, hurtighet og proporsjonalitet. $^{32}$

Formålet med materiell prosessledelse er å sikre at partene kan ivareta sine interesser i saken. Denne aktiviteten er altså rettet inn mot det innholdsmessige i saken. Selv om det å få klargjort de rettslige og faktiske spørsmålene i saken i seg selv kan være med på å «stramme opp» saken tidsmessig, er det underliggende formålet her å verne om de materielle interessene og oppnå en materielt riktig avgjørelse.

Jeg tenker at skillet mellom aktiv saksstyring og materiell prosessledelse også kan vurderes utfra i hvilken grad dommerens aktivitet griper inn i partsautonomien. Litt av grunnen til at materiell prosessledelse har vært så omdiskutert, er nettopp konflikten med disposisjons- og

\footnotetext{
${ }^{29}$ NOU 2001: 32 A s. 134.

${ }^{30}$ NOU 2001: 32 A s. 134.

${ }^{31}$ Eldjarn (2016) s. 124.

32 Eldjarn (2016) s. 121.
} 
forhandlingsprinsippene. Idet dommeren yter bistand til én av partene i saken, svekkes også dommerens nøytralitet.

\subsubsection{Bevisavskjæring}

En tredje måte å legge til rette for et godt avgjørelsesgrunnlag, er å beskjære det. I mange saker har partene et $\varnothing n s k e$ om å vise retten sakens fulle bredde. Ambisjonen er god, men resultatet kan bli at retten må lete etter de sentrale bevisene i overfloden av informasjon. Selv om man ved å avskjære bevis kan risikere at viktig informasjon går tapt, er formålet tvert imot å styrke avgjørelsesgrunnlaget ved å konsentrere det.

Etter tvisteloven § 21-7 andre ledd bokstav b kan bevis som «ikke er egnet til å styrke avgjørelsesgrunnlaget nevneverdig», nektes ført. Bestemmelsen går lenger enn det som tidligere fulgte av tvistemålsloven. ${ }^{33}$ Både i situasjonen der retten ikke har behov for flere bevis om det samme bevistemaet og situasjonen der beviset $i$ seg selv har for liten bevisverdi er omfattet av bestemmelsen. Behovet for bevisføring kan være vanskelig å anslå under saksforberedelsen, og det gjør at retten i en del tilfelle må avskjære bevis så sent som under hovedforhandlingen. Noen ganger kan det være vanskelig å vite betydningen av beviset før det er ført for retten. For at bevisavskjæring skal kunne være et hensiktsmessig virkemiddel for å oppnå et godt faktisk avgjørelsesgrunnlag, må imidlertid retten basere sin vurdering av bevisverdien på de opplysninger partene gir i sitt bevistilbud. Etter tvisteloven § 21-6 annet ledd skal parten angi hva beviset skal godtgjøre, og «kort redegjøre for viktig informasjon som vil bli gitt ved beviset, så langt parten ikke kan regne med at motparten er kjent med denne».

Tvisteloven $\S 21-7$ andre ledd bokstav b har paralleller til § 21-8 om proporsjonalitet. Etter $§ 21-8$ er det likevel ikke ønsket om et godt avgjørelsesgrunnlag som er målet med bestemmelsen, men å tilpasse bevisføringen til tvistens betydning, og dermed imøtekomme overordnede sivilprosessuelle mål om akseptable prosesskostnader og en avgjørelse innen rimelig tid.

\subsection{Hvilket ansvar har dommeren?}

\subsubsection{Innledning}

Det rettslige avgjørelsesgrunnlaget er, som nevnt tidligere, rettens ansvar. Selv om det faktiske avgjørelsesgrunnlaget som hovedregel er partenes ansvar, kan retten på flere forskjellige måter legge til rette for et godt avgjørelsesgrunnlag, men det må også vurderes hvilket ansvar dommeren har for å gjøre dette. Har dommeren en plikt til å handle? Eller bare et mer generelt ansvar for å gripe inn om det bærer helt galt av sted? Jeg vurderer spørsmålet opp mot de tre fremgangsmåtene beskrevet ovenfor for å legge til rette for et godt faktisk avgjørelsesgrunnlag.

\subsubsection{Aktiv saksstyring}

Når det gjelder spørsmålet om aktiv saksstyring, står det eksplisitt i tvisteloven § 11-6 første ledd at «retten skal legge en plan for behandlingen av saken og følge den opp slik at saken effektivt og forsvarlig kan bringes til avslutning». ${ }^{34}$ Denne plikten er som nevnt presisert i § 9-4, som inneholder en liste over hvilke spørsmål retten skal drøfte med partene på planmøtet. Klarere kan det nesten ikke formuleres. Gjennom konkrete regler forplikter retten seg til å handle, og rettspraksis gir eksempler på at staten har måttet stå ansvarlig når saksstyringen ikke har vært forsvarlig. Et eksempel er saken mellom Skien papirindustri og Staten v/Domstoladministrajonen, inntatt i Rt. 2014 s. 571. Skien papirindustri tapte en erstatningssak i Agder lagmannsrett basert på et grunnlag som ikke hadde vært

\footnotetext{
${ }^{33}$ Tvml. § 189 første ledd nr. 2 og 3. NOU 2001: 32 B s. 949.

${ }^{34}$ Min kursivering.
} 
gjenstand for behandling. Høyesterett slo fast at lagmannsretten hadde brutt det kontradiktoriske prinsipp ved å ikke ikke ta opp med partene at den ville avgjøre tvisten på dette grunnlag og at dette måtte anses som en «grovere» feil. ${ }^{35}$ Staten v/Domstoladministrasjonen ble derfor dømt til å betale Skien papirindustris sakskostnader både for lagmannsretten og Høyesterett.

Et annet eksempel på brudd på plikten til aktiv saksstyring er behandlingen av saken i HR-2010857-U mellom B og A, der det gikk 2,5 måneder fra ankeforhandlingen til dom forelå. Anken ble imidlertid ikke tillatt fremmet fordi det etter Høyesteretts ankeutvalgs syn var utelukket at feilen kunne ha fått betydning for utfallet. Utvalget understreket imidlertid at saksbehandlingstiden ikke var i tråd med «de generelle krav til en rask effektiv og tillitsskapende behandling, jf. tvisteloven § 1-1 første ledd, den aktuelle dommerens plikt til aktiv saksstyring eller tvisteloven $\S 11-6$ første ledd, eller embetslederens plikt til å påse at denne plikten følges opp, jf. § 11-7 første ledd». ${ }^{36}$ Saken gjaldt endring av dom om fast bosted og samvær med barn, og ankeutvalget uttalte at denne typen saker «skal ha prioritet».

Det finnes likevel en grense for rettens ansvar for saksbehandlingen. I saken A mot Staten v/Domstoladministrasjonen, inntatt i Rt. 2012 s. 1743, hadde saken versert for tingretten i nesten tre år før det ble inngått forlik. Høyesterett mente at selv om tingretten i perioder burde ha sørget for bedre fremdrift i saksforberedelsen, burde også saksøkeren ha fulgt opp saken bedre. Anken ble derfor forkastet.

\subsubsection{Materiell prosessledelse}

Når det gjelder rettens ansvar for å drive materiell prosessledelse, er vurderingen noe annerledes.

Riktignok står det i tvisteloven $§ 11-5$ at retten skal gi partene veiledning, men formuleringene av hva retten faktisk skal er langt vagere formulert enn i § 9-4 om aktiv saksstyring. Jo vagere formuleringen er for hva retten skal gjøre, jo høyere blir dommerens inngrepsterskel.

Tvisteloven § 11-5 om rettens veiledningsplikt inneholder regler både om prosessuell prosessledelse og materiell prosessledelse. Første ledd, som gjelder den prosessuelle prosessledelsen, forplikter retten til å gi veiledning om «regler og rutiner for saksbehandlingen». Det er selvfølgelig fint å ha en generell bestemmelse om veiledning om de formelle forhold, men reglene om aktiv saksstyring vil i stor grad sluke behovet for en slik bestemmelse.

Bestemmelsens andre til syvende ledd gjelder den materielle prosessledelsen. En innfallsvinkel til disse leddene er å trekke et skille mellom ansvaret for å klargjøre og ansvaret for å veilede. Retten har plikt til å klargjøre, se eksempelvis i bestemmelsens tredje ledd, der «retten skal virke for at tvistespørsmål blir klarlagt», mens ansvaret for å veilede er i bestemmelsens fjerde og femte ledd begrenset til «kan». ${ }^{37}$ I bestemmelsens fjerde og femte ledd kan retten oppfordre en part til å ta standpunkt til rettslige og faktiske spørsmål, og retten kan oppfordre til å tilby bevis. Perspektivet for klargjøring og veiledning er også ulik. Ved klargjøring tas det utgangspunkt i partenes eksisterende prosessopplegg, mens veiledningen peker i større grad på løsninger utenfor det eksisterende. ${ }^{38} \mathrm{Jo}$ lenger dommeren trår utenfor partenes eksisterende prosessopplegg, jo større er faren for å komme i konflikt med partenes autonomi, prinsippet om dommerens nøytralitet og av og til også i strid med $\emptyset$ nsket om en konsentrert og hurtig saksbehandling. Selv om bestemmelsen åpner for at dommeren kan gi veiledning, er skillet mellom klargjøring og veiledning med på å mane til forsiktighet med hensyn til veiledningen.

\footnotetext{
${ }^{35}$ Rt. 2014 s. 571 avsnitt 16.

${ }^{36}$ HR-2010-857-U.

${ }^{37}$ Min kursivering.

${ }^{38}$ Eldjarn (2016) s. 16.
} 
I småkravsaker stiller dette seg litt annerledes. Her er partene ofte selvprosederende, og det tilsier et $\varnothing \mathrm{kt}$ behov for veiledning. I tvisteloven $\S 11-5$ sjette ledd er det eksplisitt regulert at retten under sakens gang skal ta «særlig hensyn» til det behov parter uten prosessfullmektig har for veiledning. I tillegg er det satt inn en særskilt regulering i kapittelet om småkravprosess, der det står i § 10-2 at retten skal gi den nødvendige veiledning under saksforberedelsen, for å bringe på det rene om det er noe mer som bør foretas på dette stadiet av saken.

Regelen om preklusjon av for sent fremsatte prosesshandlinger gjelder ikke i småkravsakene. ${ }^{39}$ For saker som behandles etter allmennprosessen, er det oppstilt en preklusjonsregel i tvisteloven § 9-16. Etter denne bestemmelsen kan «en part ikke mot motpartens protest sette fram nye krav, utvide påstanden til et framsatt krav, sette fram et nytt påstandsgrunnlag eller tilby nye bevis med mindre det skjer før hovedforhandlingen og er foranlediget av motpartens sluttinnlegg, eller retten tillater det». For saker som behandles etter reglene om småkravprosessen angis det i § 10-2 hvilke bestemmelser fra kapittel 9 som skal gjelde tilsvarende i småkravsaker. § 9-16 er ikke en av disse, og kapittel 10 om småkravprosessen inneholder heller ikke noen alternativ preklusjonsregel. Mangelen på preklusjonsregel gir retten fleksibilitet, men den gjør også saksbehandlingen mindre forutberegnelig. Retten kan under sluttbehandlingen drive veiledning for å få avklart rettslige og faktiske spørsmål i saken. Reguleringen skaper mange problemstillinger for dommerne, og spørsmålet om veiledning beror nesten utelukkende på dommerens skjønn. ${ }^{40}$ Det gjør veiledning i småkravsaker vanskelig og uforutsigbar.

I norsk rett har vi få eksempler på at retten har plikt til å drive veiledning, men påvirkning utenfra kan endre dette. EU-retten synes å stille strengere krav til dommeraktivitet for å få de faktiske elementene på plass i saken, og da særlig i forbrukersaker. Dette får betydning for nasjonale domstoler innen EU, som jo er forpliktet til å anvende EU-forbrukerjussen. I en nederlandsk sak for EUdomstolen mellom Froukje Faber og Autobedrijft Hazet Ochten BV, gikk retten langt i å pålegge retten en plikt til å unders $\varnothing$ ke på eget initiativ om en part var forbruker eller ikke, se C-497/13 Faber. Forbrukervernet står sterkt i EU, og forbrukeren synes nesten automatisk å få tildelt en posisjon som en svakere part som trenger beskyttelse. Retten gis dermed nærmest en bevisføringsplikt for å få avklart om parten er i denne posisjonen eller ikke. En slik plikt for domstolene synes umiddelbart fremmed etter norske forhold, men vi har også en åpning i tvisteloven § 21-3 annet ledd annet punktum, der retten kan sørge for bevisføring med mindre partene motsetter seg dette. En slik forpliktelse kan dommeren pålegges i situasjoner der bevisføringen vil kunne få avgjørende betydning for utfallet av saken. ${ }^{41}$ Dersom parten er selvprosederende $\varnothing$ ker ansvaret for å oppfordre til bevisførsel. Problemet er likevel at spørsmålet om når en slik forpliktelse slår inn er skjønnsmessig. Dermed er man kanskje like langt.

\subsubsection{Bevisavskjæring}

Når det gjelder bevisavskjæring, har dommeren også en forpliktelse til å foreta bevisavskjæring av eget initiativ. Dette fremkommer som nevnt av tvisteloven § 21-7 annet ledd. Bestemmelsen er imidlertid en «kan»-bestemmelse og det gjør at utøvelsen av den blir skjønnspreget. Hvordan avgjørelsesgrunnlaget skjæres til, vil derfor håndteres ulikt fra dommer til dommer.

\footnotetext{
${ }^{39}$ Det er imidlertid forslag fra Justis- og beredskapsdepartementet om å innføre en preklusjonsfrist også i småkravprosessen, se Forslag til endringer i tvisteloven - tvistelovevalueringen sendt på høring i juli 2018 s. 1920.

${ }^{40}$ Eldjarn (2016) s. 282.

${ }^{41}$ Ot.prp. nr. 51 (2004-2005) s. 407.
} 


\section{Oppsummering}

I Factoring Finans-saken ble det ytt materiell prosessledelse, men på et svært sent tidspunkt. Det historien ikke sier noe om, er når dommeren ble oppmerksom på at spørsmålet om overdragelse ikke var avklart. Dersom dommeren ble klar over spørsmålet tidligere under forhandlingen, men ikke stilte det før etter prosedyrene, må det kunne sies at dette er en materiell veiledning som ikke står i stil med dagens standard. En av «bærebjelkene» i tvistelovsreformen er å få dommere til å drive aktiv saksstyring. Ved at dommeren på et tidlig tidspunkt får oversikt over saken, herunder både de rettslige spørsmålene og hvilken bevisføring som skal underbygge partenes påstander, vil vi forhåpentligvis redusere muligheten for at sakens avgjørende problemstilling først blir stilt på slutten av prosedyren i Høyesterett. 